\title{
Perception of Beef Cattle Breeders on Utilization of Banana Stems as Creature Nourish in Marioriawa Area, Soppeng Regency
}

\author{
Sitti Nurani Sirajuddin'1, Ikrar M Saleh ${ }^{1}$, Jamilah Mustabi ${ }^{2}$ and Syamsinar ${ }^{3}$ \\ ${ }^{1}$ Department of Socio-Economic of Animal Husbandry, Faculty of Animal Husbandry Hasanuddin University, Indonesia \\ ${ }^{2}$ Department of Nutrition and Feed Livestock, Faculty of Animal Husbandry Hasanuddin University, Indonesia \\ ${ }^{3}$ Department of Agribusiness, Faculty of Agriculture, Islamic University of Makassar, Indonesia
}

Correspondence Author: Sitti Nurani Sirajuddini, Department of Socio-Economic of Animal Husbandry, Faculty of Animal Husbandry Hasanuddin University

Email: sitti.nurani@unhas.ac.id

Received date: 28 August 2019, Accepted date: 2 December 2019, Online date: 20 December 2019

Copyright: (C) 2019 Sitti Nurani Sirajuddin et al., This is an open-access article distributed under the terms of the Creative Commons Attribution License, which permits unrestricted use, distribution, and reproduction in any medium, provided the original author and source are credited.

\begin{abstract}
This study aimed to determine the perception of farmers in processing of banana stems as animal feed. The research was conducted in June 2019 until July 2019. This investigate was conducted in Patampanua Town, Marioriawa Subdistrict, Soppeng Rule. The sort of inquire about utilized was clear. This inquire about utilized overview strategy. The sort of information utilized in this ponder was subjective information and quantitative information. Information sources were essential information and auxiliary information. The populace in this investigate was the full breeder of hamburger cattle in Patampanua Town, Marioriawa Sub area, Soppeng Rule. The number of populaces in this investigate was 78 breeders of meat cattle and all populace taken as test of inquire about. The information collection strategies utilized in this think about was perception and meet. Information examination utilized in this investigate was clear. The result of investigate the farmers' recognition of making meat cattle from banana stems is exceptionally positive (supportive) since it has never been done some time recently.
\end{abstract}

Keywords: banana stems, animal feed, cattle, perception.

\section{INTRODUCTION}

The improvement of animals sub-sector in Indonesia must be moved forward, considering that request for animal's products in Indonesia, for the most part, tends to extend from year to year. Usually in line with the expanded mindfulness of the wholesome needs of the community, but not adjusted by the increment in animal's populace. Animals as one of the rural sub-sector was a significant portion of the victory of the segment in Indonesia. The vision of agrarian advancement was a refined animals industry by the mechanical base. Animals advancement as and necessarily portion of rural improvement contributes to the fulfilment of creature protein to extend the utilization of creature protein for the community [1] and [2]. Paradigm cultivate development was the realization of a solid society and beneficial and imaginative through an intense cultivate based on nearby assets [3] and [4]. Beef cattle are one of the animals that can be depended upon as a supplier of meat. This is often awfully beneficial for breeders on the off chance that they can take advantage of this opportunity well. In expansion, the fulfilment of creature protein can increment the dietary needs of individuals to progress insights [5]. The feed is exceptionally persuasive on the efficiency of hamburger cattle so that it influences the appearance (weight). Bolstering gives a huge impact. This is often in agreement with the conclusion of [6]. The source of agrarian squander can be devoured straightforwardly by animals. Also, its formative activities can be carried out through the ensilage handle. In ensilage innovation, natural forms (silage) and chemistry (ammonification) are known.

The silage technology process generally uses functional microbial anaerobes. The fermented feed can maximize feed absorption so that animal body weight increases faster. Preparation of rations using forage as the main ingredient then supplemented with supplements, and the addition of additives such as probiotics and boosters of enzyme synthesis such as pro-vitamins will ensure adequate nutrition for livestock. Providing proper and quality feed can produce cattle that have suitable body weight. Feeding can influence growth, product, and reproduction. This is consistent with the opinion of [7] that the contribution of feed to animal health, production and productivity of livestock is vital. The feed is a critical factor in the livestock business because it is 70$75 \%$ of the total production cost. Naturally, Indonesia as an agrarian country has considerable potential to be able to fulfil its own food needs. Still, so far there have not been any serious efforts from the Government, both efforts to overcome the problem 
and attempts to exploit the real potential. In the dry season, the animal feed can only be obtained in the form of dry feed ingredients such as rice straw or corn trees. This feed pattern is a pattern of adaptation that can be applied to livestock management in the dry season due to limited forage. Giving feed with dry feed ingredients will reduce the efficiency of feed absorption because the supply of protein into the body of the animal becomes limited. In this condition, it takes an intake (feed) in the form of protein from other sources such as those contained in corn cereal flour (corn gluten meal) or bran [6].

\section{MATERIALS AND METHODS}

The inquire about was conducted in June 2019 July 2019. This inquires about was conducted in Patampanua village, Marioriawa Sub area, Soppeng Regency. The sort of investigating utilized is graphic. This inquires about employments overview strategy. A study strategy is utilized to know recognition ranchers on the utilization of banana stems as creature nourish. The type of data used in this study is qualitative data and quantitative data. Data sources are primary data is data sourced from direct interviews with the breeders by using questionnaires such as identity data respondents. The population in this research is the whole breeder of beef cattle in Patampanua Village, MarioriawaSubdistrict, and Soppeng Regency. The number of population in this inquire about is 78 breeders of meat cattle and all population taken as a test of investigating. The information collection procedures utilized in this consider is perception and meet. Information investigation utilized in this inquire about is the descriptive measurement.

\section{Processing of Feed from Banana Stems}

\section{RESULTS AND DISCUSSION}

Processing of feed by utilizing plantation waste, namely banana stems which are processed into animal feed. Processing by using materials such as molasses with a dose of 1 cup, 3 scoop water, $1 / 2$ cup microbes, and 1 cup salt mixed homogeneously and left for 15 minutes. Then the banana stem in copper is then flattened with a thickness of approximately $20 \mathrm{~cm}$. Continuing the second layer, the tofu dregs were evenly spread over the banana trunks that had been cooperated, then the third layer was placed in $2 \mathrm{~kg}$ of minerals evenly, then the bran was spread evenly on the fourth layer. After that, the solution which was left to stand for 15 minutes was levelled over the bran layer. Then insert into the drum provided. Then store for 1 x 24 hours or 7 x 24 hours.

\section{Farmers' perception of making an animal feed from banana stems}

Knowledge of the community in Patampanua Village, Marioriawa Sub-District on how to process forage preservation such as making silage from rice straw in the medium category[8]. Because the silage fermentation process can increase the nutritional value of feed and can also overcome the availability of animal feed throughout the year. This is consistent with the opinion of [9] that the benefits of silage making are the supply of livestock food in the dry season, accommodating excess forage for the rainy season and optimally utilizing it, utilizing associated products from agricultural and plantation waste. The advantages of silage products where the silage nutritional value is equivalent to fresh forage can be even higher, favoured by livestock and available throughout the year both rainy and dry seasons. Farmers/ranchers in the village of Patampanua, Marioriawa Sub-district, Soppeng Regency carry out feed processing by utilizing banana stems as animal feed for fermentation by utilizing microbes still in the starting stage so that farmers' perceptions of the use of banana stems are very helpful in raising beef cattle. Banana stems have many benefits after processing because the process of mixing is done by mixing forages and concentrates so that livestock needs are met and can increase livestock productivity. This is in accordance with the opinion of [10] that feeding at different levels will cause physiological conditions such as respiratory frequency, pulse rate, and different body temperatures due to differences in the fermentation or metabolic processes that occur in the body. Giving feed by giving concentrates with forages will increase livestock productivity, this is in accordance with the opinion of [11] which states that feed is an ingredient that is eaten and digested by an animal and is able to provide needed nutrients in accordance with livestock needs for growth, fattening, reproduction (lust, conception, pregnancy) and lactation (milk production). Another reason why the feed is one of the most important factors besides seeds and management in raising livestock, that feed is the best in animal nutrition needs. The weakness of livestock production systems generally lies in the uncertainty of feed and health management. Feed limitations cause the capacity of livestock in an area to decrease or can cause normal production and reproductive disorders.

\section{CONCLUSIONS}

The farmers' perception of the manufacture of banana stems (fermentation) as beef cattle feed is very positive because this activity has never been done

\section{Acknowledgements}

Thanks to the Ministry of Technology and Higher Education which has provided opportunities to activities of regional partnership program (PKW) 


\section{REFERENCES}

[1] Tanri Giling Rasyid., ST.Rohani, Muhammad Aminawar, Muhammad Darwis. The Level of Social Capital and Its Effect on the Participation of Farmers on Goat Livestock Business Development in Jeneponto Regency South Sulawesi ProvinceIndonesia .2018. Advances in Environmental Biology 2018 February; 12(2): pages 1-3 DOI: 10.22587/aeb.2018.12.2.1 Research Article AENSI Publications

[2] Lestari, S.V, Sirajuddin, NS.Imran, M.2013. Persepsi masyarakat terhadap limbah sapi potong.Jurnal Ilmu Ternak.2 (1):3941

[3] Maksudi, S.Wigati dan E.Wiyanto.2015. Produksi pupuk organic padat dan cair dari sludge biogas dan bio urin. Jurnal pegabdian Masyarakat. Fakultas Peternakan Universitas Jambi. 30(1):73:80

[4] Sirajudddin, S.N.A.Asnawi, S.Syawal, M.Jamal.2016. Response of cattle breeders' silage in Soppeng regency, South Sulawesi Province. American Eurasian Journal of Sustainable Agriculture.10 (2):33-36

[5] Abdullah A, Jamila, A. Amrawati, St Nurlaela, A. Amrullah, 2017. Analysis of the Determining Factors on the Performance of Extension Officers for the Transfer of Livestock Feed Technology. American-Eurasian Journal of Sustainable Agriculture, 11(5): 72-76.

[6] Sirajuddin SN, Hastang,St.rohani,M.Erik Kurniawan. 2016.Level Technology Adoption and Characteristic Cattle Breeders who following Bachelor Village Building. American-Eurasian Journal of Sustainable Agriculture .10(5): 28-32

[7] Eddy BT,Roessali W and Marsuki S.2013. Dairy cattle faremrs behavior and factors affecting the effort to enhance the economics of scale at Getasan district Semarang regency.J Indoensian Trop.Anim Agric.37:34-40

[8] Huda,S dan W.Wikanta. 2016. Pemanfaatan limbah kotoran sapi menjadi pupuk organic sebagai upaya mendukung usaha peternakan sapi potong di kelompok tani ternak madiri jaya desa Moropelang Kec.babat Kab.Lamongan.Axiologiya. Jurnal Pengabdian Masyarakat. Surabaya 1(1):23-31

[9] Adityawarman, S.A.Salundik,Lucia, A.2015.Pengolahan limbah ternak secara sederhana di desa Patallassang Kabupaten Sinjai Sulawesi Selatan.Jurnal Teknologi Hasil Ternak.Fakultas Peternakan.IPB.Bogor. 3(3):171-177

[10] Sirajuddin SN.AR.Siregar, P.Mappigau.2017. Adoption Rate of Beef Breeders Technology Following Partnership System in Barru Regency. . American Eurasian Journal of Sustainable Agriculture.11 (6):31-34

[11] Setiawan, S Benito,T and B.Yuli AH.2013. Pengolahan limbah ternak pada pengelolaan sapi potong di Kabupaten Majalengka. Jurnal Ilmu Ternak.Fakultas Peternakan Universitsa Padjajaran. 13(1):24-30 